\title{
Production of Antifungal Chitinase by Aspergillus niger LOCK 62 and Its Potential Role in the Biological Control
}

\author{
Maria Swiontek Brzezinska • Urszula Jankiewicz
}

Received: 19 March 2012/ Accepted: 14 July 2012/Published online: 26 August 2012

(C) The Author(s) 2012. This article is published with open access at Springerlink.com

\begin{abstract}
Aspergillus niger LOCK 62 produces an antifungal chitinase. Different sources of chitin in the medium were used to test the production of the chitinase. Chitinase production was most effective when colloidal chitin and shrimp shell were used as substrates. The optimum incubation period for chitinase production by Aspergillus niger LOCK 62 was 6 days. The chitinase was purified from the culture medium by fractionation with ammonium sulfate and affinity chromatography. The molecular mass of the purified enzyme was $43 \mathrm{kDa}$. The highest activity was obtained at $40{ }^{\circ} \mathrm{C}$ for both crude and purified enzymes. The crude chitinase activity was stable during $180 \mathrm{~min}$ incubation at $40{ }^{\circ} \mathrm{C}$, but purified chitinase lost about $25 \%$ of its activity under these conditions. Optimal $\mathrm{pH}$ for chitinase activity was $\mathrm{pH} 6-6.5$. The activity of crude and purified enzyme was stabilized by $\mathrm{Mg}^{2+}$ and $\mathrm{Ca}^{2+}$ ions, but inhibited by $\mathrm{Hg}^{2+}$ and $\mathrm{Pb}^{2+}$ ions. Chitinase isolated from Aspergillus niger LOCK 62 inhibited the growth of the fungal phytopathogens: Fusarium culmorum, Fusarium solani and Rhizoctonia solani. The growth of Botrytis cinerea, Alternaria alternata, and Fusarium oxysporum was not affected.
\end{abstract}

\footnotetext{
M. S. Brzezinska ( $\square)$

Department of Environmental Microbiology and Biotechnology, Institute of Ecology and Environmental Protection, Nicolaus

Copernicus University, Gagarina 9, Toruń, Poland

e-mail: swiontek@umk.pl

U. Jankiewicz

Department of Biochemistry, Warsaw University of Life

Sciences, Nowoursynowska 159, Warsaw, Poland
}

\section{Introduction}

Chitinases (E.C. 3.2.1.14.) are enzymes that are capable of hydrolyzing chitin to its oligomers and/or monomers. Chitinase from various origins has different enzymological properties and usually constitutes a complex chitinolytic enzyme. These enzymes play an important role in the nutrition and parasitism of bacteria and fungi. They are also involved in fungal morphogenesis and autolysis $[9,26$, 27]. In recent years, the search for microorganisms antagonistic toward fungi has intensified due to the fact that they are causative factors of many plant diseases. This is usually associated with the production of antifungal compounds and extracellular hydrolytic enzymes (chitinase and 1,3- $\beta$ glucanase) [21]. Chitinolytic enzymes are able to lyse the cell wall of many fungi. The microorganisms that produce these enzymes chitynolytic enzymes are able to destroy the cell wall of many fungi. The microorganisms that produce these enzymes are capable of eradicating fungal diseases that are a problem for global agricultural production. Molds are among the most aggressive plant pathogens. They are routinely combated using chemical fungicides. However, the excessive use of these compounds, which has increased almost threefold over the past 40 years, has led to problems related to contamination and degradation of the natural environment. These substances can be lethal to beneficial insects and microorganisms in the soil, and may also enter the food chain [5].

Some mold species which produce very strong endochitinases-Trichoderma harzianum and Fusarium chlamydosporum-are of particular significance, when it comes to plant protection. Chitinase produced by bacteria often presents antagonistic activity against phytopathogenic fungi. Chitinase encoding genes were reported, cloned, and characterized in bacteria [29], yeast, plants, 
and fungi. Among the chitinolytic fungi, the best-known are the fungicidal properties of Trichoderma harzianum. Chitynolytic microorganisms may be an alternative to chemical agents and could be employed as natural plant protection methods against fungal diseases. To this end, microorganisms able to synthesize compounds that naturally inhibit the growth of phytopathogenic fungi are being searched for. Compared to synthetic fungicides, they do not contaminate the environment, this being a crucial factor in increased interest in the use of biological methods to combat plant pathogens.

The aim of the present study was to determine the potential of Aspergillus niger LOCK 62 chitinase. The chitinase was purified and characterized, and its thermal stability was investigated. The antifungal activity of the crude and purified chitinase was also tested.

\section{Materials and Methods}

\section{Microorganisms}

The microorganism studied was Aspergillus niger LOCK 62, which was obtained from the Institute of Biotechnology and Antibiotics in Warsaw (Poland). The culture was maintained on Czapek Dox medium (Difco) slants supplemented with $10 \mathrm{~g} / \mathrm{l}$ of colloidal chitin, sub-cultured regularly every 2 weeks and stored at $+4{ }^{\circ} \mathrm{C}$. Spore suspension was prepared by agitation of Czapek Dox cultures with a $0.1 \mathrm{v} / \mathrm{v} \%$ solution of Tween 80 up to a concentration of $10^{7}$ spores $/ \mathrm{ml}$.

Eight pathogenic fungi were used as indicator strains: Alternaria alternata (isolate from kohlrabi), Fusarium oxysporum (isolate from potato), Fusarium solani (isolate from parsley), and Botrytis cinerea (isolate from tomato). All fungi were from the Bank of Plant Pathogens in Poznan. The studies also included Fusarium culmorum (isolate from pine) and Rhizoctonia solani (isolate from pine). These two plant pathogens were purchased from the Faculty of Forestry, Agricultural University in Poznan.

\section{Medium and Culture Conditions}

The spore suspension was inoculated into $500 \mathrm{ml}$ of liquid medium containing different carbon and nitrogen sources. Composition of medium 1 was: $0.3 \% \quad \mathrm{NaNO}_{3} ; 0.1 \%$ $\mathrm{KH}_{2} \mathrm{PO}_{4} ; 2 \%$ saccharose; $0.05 \% \mathrm{KCl} ; 0.05 \% \mathrm{MgSO}_{4}$. $7 \mathrm{H}_{2} \mathrm{O}$; and $0.001 \% \mathrm{FeSO}_{4} \cdot 7 \mathrm{H}_{2} \mathrm{O}$. The $\mathrm{pH}$ of the medium was adjusted to 6.5. The composition of medium 2 was: $0.05 \% \mathrm{KH}_{2} \mathrm{PO}_{4}, 0.05 \% \mathrm{~K}_{2} \mathrm{HPO}_{4}, 0.003 \% \mathrm{MgSO}_{4} \cdot 7 \mathrm{H}_{2} \mathrm{O}$, and $0.15 \%$ yeast extract. The $\mathrm{pH}$ of the medium was adjusted to 6.5. To each medium, a single substrate was added for microbial chitinase production (2\% shrimp shell waste, crab shell powder chitin, or colloidal chitin). Cultivation was at $26^{\circ} \mathrm{C}$ for 10 days with shaking $(100 \mathrm{rpm})$ and then cultures were centrifuged at $10,000 \times g$ for $10 \mathrm{~min}$ at $+4{ }^{\circ} \mathrm{C}$. Colloidal chitin was prepared using the method of Lingappa and Lockwood [17]. The shrimp shell waste was purchased by Krymar facility in Iłow. Chitin powder from shell crab was purchased from Sigma-Aldrich. All experiments were conducted in triplicate.

\section{Chitinase Activity}

The activity of chitinase in the supernatant was determined using the synthetic fluorogenic substrate 4-methylumbelliferyl $N$-acetyl- $\beta$-D-glucosaminide (4MU-GlcNac) (SigmaAldrich) [10, 19]. The reaction mixture contained: $1 \mathrm{ml}$ crude chitinase, $0.125 \mathrm{ml}$ substrate $4 \mathrm{MU}-\mathrm{GlcNac}$ solution (the final concentration in sample was $50 \mu \mathrm{M} / 1$ ) and $0.125 \mathrm{ml}$ of phosphate buffer $(50 \mathrm{mM}, \mathrm{pH} 7)$. The control, prior to addition of the substrate, was treated with $0.1 \mathrm{ml}$ solution of $\mathrm{HgCl}_{2}$ to deactivate the enzymes present in the sample (final concentration: $4 \mathrm{mM} / \mathrm{l}$ ). The mixture was incubated in the dark for $1 \mathrm{~h}$ at the temperature of $40{ }^{\circ} \mathrm{C}$. After incubation, enzymatic reactions were stopped by adding $\mathrm{HgCl}_{2}$. The released methylumbelliferone (MU) was measured fluorimetrically at $318 \mathrm{~nm}$ excitation and 445 nm emission using Hitachi F 2500 spectrofluorometer. In order to determine the optimum $\mathrm{pH}$ of enzyme activity different buffers were used ( $\mathrm{pH} 4-8)$ at $50 \mathrm{mM}$ concentrations. The enzyme activity $(U)$ was defined as nM MU released per $\mathrm{ml}$ per $\mathrm{h}$.

\section{Purification of Chitinase}

All purification procedures were carried out at $4{ }^{\circ} \mathrm{C}$. After cultivation of the Aspergillus niger LOCK 62 isolate in medium 2 containing colloidal chitin for 6 days, the cells were removed by centrifugation at $10,000 \times g$ for $20 \mathrm{~min}$. Chitinase was purified by a two-step purification involving ammonium sulfate precipitation and chitin affinity chromatography.

Fractionation with ammonium sulfate: The supernatant (2 1) was precipitated using ammonium sulfate to $85 \%$ saturation. The protein deposit was obtained by centrifugation $(16,000 \times g, 30 \mathrm{~min})$, dissolved in $50 \mathrm{mM}$ sodium phosphate buffer ( $\mathrm{pH}$ 7.0) and dialyzed against the same buffer overnight.

Chitin affinity chromatography was done according to the modified method of Escott et al. [7]. The same volume of $1 \%(\mathrm{w} / \mathrm{v})$ colloidal chitin in $50 \mathrm{mM}$ sodium phosphate buffer ( $\mathrm{pH}$ 7.0) was added to desalted enzyme solution and incubated for $2 \mathrm{~h}$ at $4{ }^{\circ} \mathrm{C}$. This solution was centrifuged $(10,000 \times g, 15 \mathrm{~min})$, then the supernatant was discarded, and the deposit was washed two times with $50 \mathrm{mM}$ sodium 
phosphate buffer ( $\mathrm{pH} 7.0)$. The bound proteins were eluted with $50 \mathrm{mM}$ acetate buffer, $\mathrm{pH}$ 4.0. The obtained preparations were centrifuged and dialyzed overnight. The thus obtained enzyme solution was used for further research. After each purification step, the activity of chitinases and protein content was determined.

\section{Determination of Protein Concentration}

Protein concentration was determined using the method of Bradford [4] with bovine serum albumin as a standard.

\section{Polyacrylamide Gel Electrophoresis}

Electrophoresis under denaturing conditions (SDS-PAGE) was performed in a $12 \%$ polyacrylamide gel according to the procedure described by Laemmli [15] in Tris-Glycine buffer $\mathrm{pH}$ 8.3. The protein bands were visualized using Coomassie Brilliant Blue R-250.

\section{Determination of Molecular Mass of the Enzyme}

The molecular mass of the enzyme was estimated by SDSPAGE. The molecular weight standards were used: phosphorylase b $(97 \mathrm{kDa})$, bovine serum albumin $(66 \mathrm{kDa})$, ovalbumin (45 kDa), carbonic anhydrase (31 kDa), soybean trypsin inhibitor $(21 \mathrm{kDa})$, and lysozyme $(14 \mathrm{kDa})$.

\section{Characteristics of Crude and Purified Chitinase}

The optimum temperature activity of crude and purified chitinase was determined in the temperature range from 40 to $70{ }^{\circ} \mathrm{C}$. The thermal stability of crude and purified chitinase was determined. The enzyme was initially preincubated at various temperatures $\left(40,50\right.$, and $\left.60^{\circ} \mathrm{C}\right)$ and at different time intervals $(0,30,60,90,120$, and $180 \mathrm{~min})$. After the heat treatment, samples were cooled and assayed for residual activity at $40{ }^{\circ} \mathrm{C}$. The optimum $\mathrm{pH}$ was determined in the range from 4.0 to 8.0. The buffer systems were as follows: $50 \mathrm{mM}$ acetate buffer for the $\mathrm{pH} 4-5$ range and $50 \mathrm{mM}$ sodium phosphate buffer for the $\mathrm{pH}$ range of 6-8. The effect of metal ions on activity was determined following pre-incubation of crude and purified chitinase for $30 \mathrm{~min}$ at $4{ }^{\circ} \mathrm{C}$ in the presence of divalent metal ions $(\mathrm{Mg}, \mathrm{Ca}, \mathrm{Hg}, \mathrm{Zn}, \mathrm{Mn}, \mathrm{Cd}, \mathrm{Pb})$ in final concentration $1 \mathrm{mM}$, after which the substrate was added and the residual activity tested.

\section{Antifungal Activity}

Crude and purified chitinase were tested for inhibitory activity against the growth of the fungal strains: Alternaria alternata, Fusarium oxysporum, Fusarium solani,
Fusarium culmorum, Botrytis cinerea, and Rhizoctonia solani. The antifungal activity of chitinase was estimated using a growth inhibition assay described earlier [30]. Antifungal activity was observed directly on petri plates of Czapek Dox (Difco) medium where the test microorganisms were placed with crude and purified chitinase on (experimental group) and without chitinase (control). Both groups were incubated for $72 \mathrm{~h}$ at $25^{\circ} \mathrm{C}$. The inhibition ratio was calculated according to the formula [30]:

Inhibition ratio $(\%)=(C-E) / C \times 100 \%$

where $C$ is the average diameter of colonies in the control, $E$ is the average diameter of colonies in the experimental group. All experiments were conducted in triplicate.

In this study, we adopted certain inhibition criteria: no inhibition (-; 0-20\%), moderate inhibition $(+; 21-30 \%)$, strong inhibition $(++; 31-50 \%)$, and very strong inhibition $(+++;>50 \%)$.

\section{Results and Discussion}

Chitinase production from Aspergillus niger LOCK 62 was best in medium 2 containing yeast extract as a source of carbon and nitrogen and colloidal chitin as the substrate for enzyme production $(65 \mathrm{nmol} \mathrm{U} \mathrm{ml} / \mathrm{h}$ on medium 1 and $82 \mathrm{nmol} \mathrm{U} \mathrm{ml} / \mathrm{h}$ on medium 2) (Fig. 1). Chitinase activities were checked 2 days after visible fungal growth appeared (Fig. 2), whereas maximum activity was observed after 6 days of cultivation.

The literature data indicate similar results in the case of Aspergillus sp. S1-13 [24]. This organism produces two endochitinases and a single exochitinase, in a solid-state

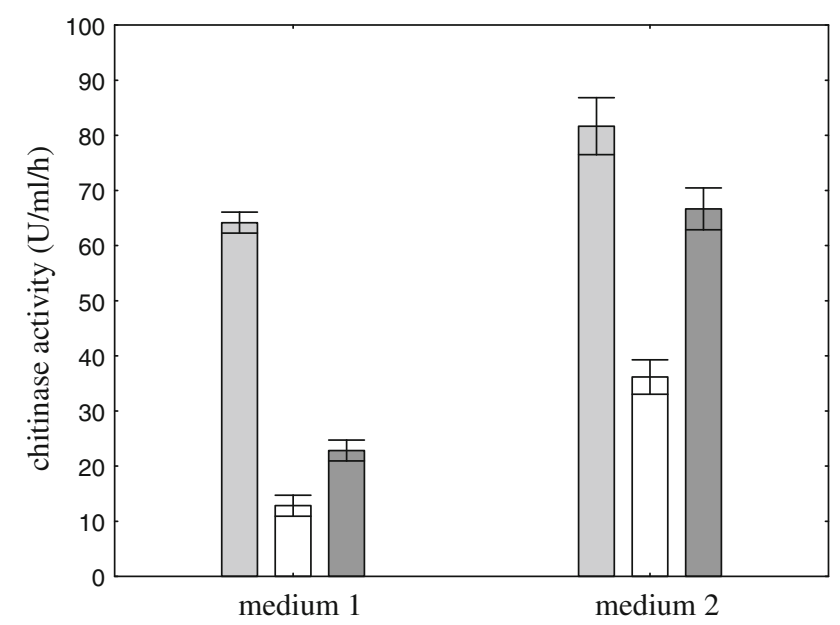

Fig. 1 Effect of composition of medium on chitinase production. To each medium, one substrate was added: colloidal chitin (light-shaded square), shrimp shell waste (dark-shaded square), and crab shell powder chitin (open square). Cultivation was performed at $26{ }^{\circ} \mathrm{C}$ for 6 days. Vertical bars represent standard deviation $(n=3)$ 
culture with shrimp shellfish waste as the substrate, in a liquid culture with shrimp shellfish waste and in a liquid culture with powdered chitin after 7 days of incubation [23]. Fourteen Penicillium strains were tested on wheat bran-crude chitin mixture medium for extracellular chitinase production in solid-state fermentation. Under the experimental conditions, Penicillium aculeatum NRRL 2129 (= ATCC 10409) was selected as the best enzyme producer. The optimum incubation period for chitinase production by the potent organism was $72 \mathrm{~h}$ [3]. Lee et al. [16] showed that the highest chitinase activity from Penicillium sp. LYG 0704 was observed on the third day of cultivation.

Summary purification steps for chitinase from Aspergillus niger LOCK62 are presented in Table 1. Ammonium sulfate precipitation and chitin affinity adsorption resulted in 2.3-fold purified enzyme preparation with high recovery of activity of $29 \%$. The specific activity of the purified enzyme was $22.5 \mathrm{U} \mathrm{mg} / \mathrm{h}$. The purity of the enzyme preparation was confirmed by electrophoresis after chromatographic separation step (Fig. 3). The molecular mass of chitinase was estimated to be $43 \mathrm{kDa}$.

Binod et al. [3] showed for Penicillium aculeatum NRRL 2129 that the yield of chitinase from SSF culture filtrate was $60.3 \%$ and the purification factor was 2.9. The molecular weight of the purified enzymes was estimated as 82.7, 44.6, 28.2, and $26.9 \mathrm{kDa}$. Lee et al. [16] purified chitinase from Penicillium sp. LYG 0704 17.6-fold with an overall yield of $8.8 \%$. The molecular weight of the enzyme was $47 \mathrm{kDa}$. Rattanakit et al. [24] purified exochitinase from Aspergillus sp. S1-13 approximately 22 -fold with $1 \%$ yield. The molecular weight of the purified chitinase was $73 \mathrm{kDa}$.

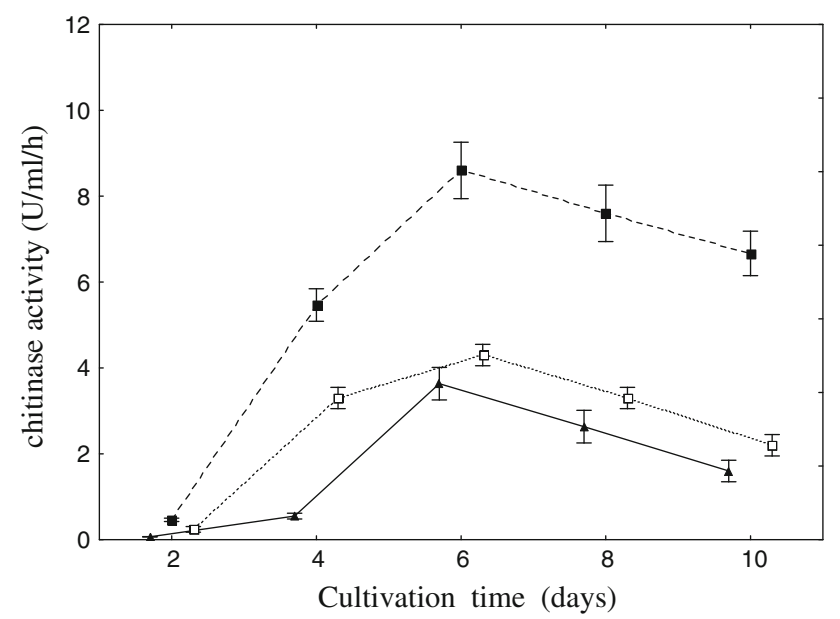

Fig. 2 Effect of cultivation time on the chitinase production. Cultivation was performed at $26^{\circ} \mathrm{C}$ on medium 2 with colloidal chitin (filled square), shrimp shell waste (open square) and crab shell powder chitin (filled triangle). Vertical bars represent standard deviation $(n=3)$
Table 1 Summary of the purification procedure for Aspergillus niger LOCK 62 chitinase

\begin{tabular}{lccccl}
\hline Step & $\begin{array}{l}\text { Total } \\
\text { protein } \\
(\mathrm{mg})\end{array}$ & $\begin{array}{l}\text { Total } \\
\text { activity } \\
(\mathrm{U})\end{array}$ & $\begin{array}{l}\text { Specific } \\
\text { activity } \\
(\mathrm{U} / \mathrm{mg})\end{array}$ & $\begin{array}{l}\text { Yield } \\
(\%)\end{array}$ & $\begin{array}{l}\text { Purification } \\
\text { factor }\end{array}$ \\
\hline $\begin{array}{l}\text { Crude enzyme } \\
\mathrm{NH}_{4} \mathrm{SO}_{4}(85 \%)\end{array}$ & 132 & 1250 & 9.46 & 100 & 1 \\
$\quad \begin{array}{l}\text { dialysis } \\
\text { Affinity } \\
\text { adsorption } \\
\text { chromatography }\end{array}$ & 16 & 360 & 16.9 & 63 & 1.7 \\
\hline
\end{tabular}

Fig. 3 SDS-PAGE analysis of purified chitinases from Aspergillus niger LOCK 62. Lane $M$ was loaded with standard marker mixture and lane 1 was loaded with the purified enzyme

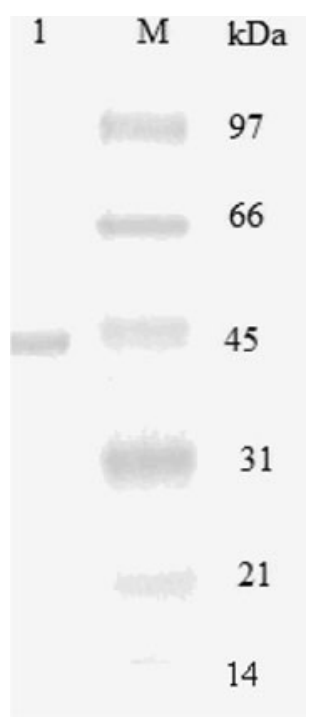

In this study, the highest activity was obtained at $40{ }^{\circ} \mathrm{C}$ for both crude and purified enzymes (Fig. 4). The optimal temperature for the activity of crude and purified chitinases from Penicillium aculeatum NRRL 2129 and Massilia timonae was $50{ }^{\circ} \mathrm{C}[1,3]$.

Thermal stability was investigated at $40-60{ }^{\circ} \mathrm{C}$ (Fig. 5). After $180 \mathrm{~min}$ of pre-incubation of crude chitinase at $40{ }^{\circ} \mathrm{C}$, a decrease of enzyme activity of about $10 \%$ was observed while with purified enzyme about $25 \%$ of activity was lost. Both the crude and the purified enzyme preparations completely lost their activity after $180 \mathrm{~min}$ of incubation at $60{ }^{\circ} \mathrm{C}$. These results were similar to those observed for chitinase from other microbial sources [16, 24]. Thompson et al. [28] reported that the chitinase isolated from Pseudomonas aeruginosa retained $90 \%$ of its activity up to $50{ }^{\circ} \mathrm{C}$ while another report shows that a chitinase from Penicillium oxalium was stable below $45^{\circ} \mathrm{C}$ [25]. The crude chitinase preparation (assuming this is what the authors meant) from Penicillium aculeatum NRRL 2129 lost $25 \%$ of its activity after incubation at $50{ }^{\circ} \mathrm{C}$ for $1 \mathrm{~h} \mathrm{[3]}$. Lee et al. [16] reported that the chitinase Penicillium sp. LYG 0704 was thermostable below the temperature of $40{ }^{\circ} \mathrm{C}$. 


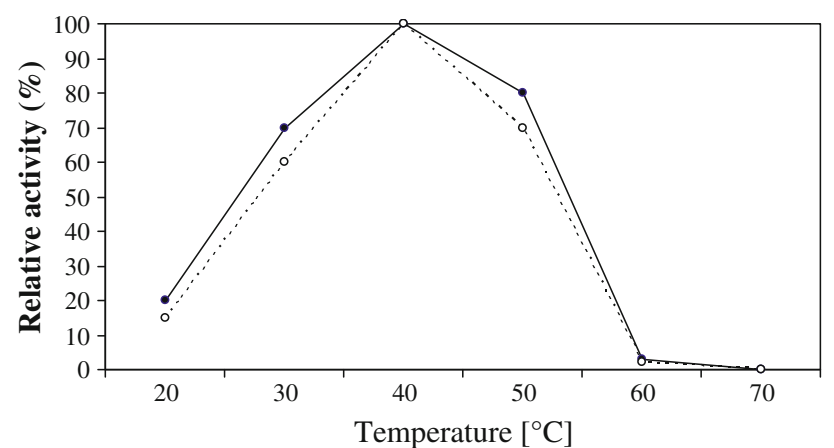

Fig. 4 Effect of temperature on the activity of chitinase from Aspergillus niger LOCK 62 (crude chitinase, filled circle; purified chitinase, open circle)

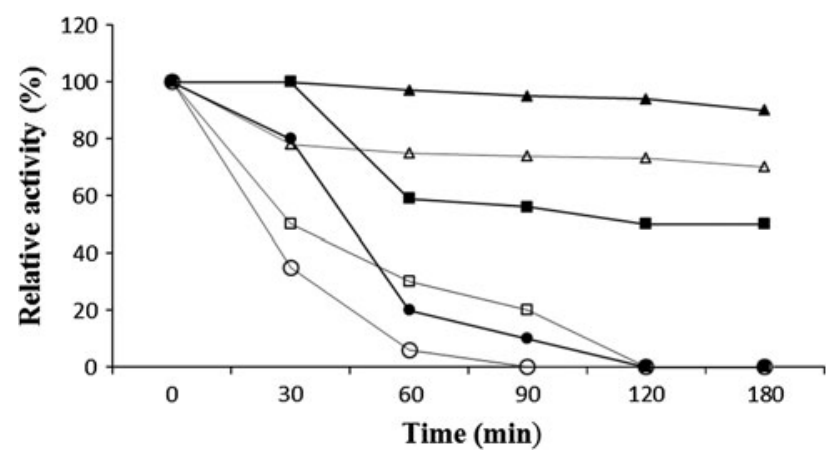

Fig. 5 Thermal stability of crude and purified chitinase $\left(40{ }^{\circ} \mathrm{C}\right.$ crude chitinase, filled triangle; $40{ }^{\circ} \mathrm{C}$ purified chitinase, open triangle; $50{ }^{\circ} \mathrm{C}$ crude chitinase, filled square; $50{ }^{\circ} \mathrm{C}$ purified chitinase, open square; $60^{\circ} \mathrm{C}$ crude chitinase, filled circle; and $60^{\circ} \mathrm{C}$ purified chitinase, open circle)

The optimal $\mathrm{pH}$ for crude chitinase produced by Aspergillus niger LOCK 62 was found to be 6.5, but for purified enzyme maximum activity was at $\mathrm{pH} 6$ (Fig. 6). Pritsch et al. [22] reported that four species of studied fungi showed differences in the $\mathrm{pH}$ optima for chitinase activity. The optimal $\mathrm{pH}$ for the chitinase activity of Lactarius subdulcis was $\mathrm{pH}$ 6.0, but chitinase from Xerocomus cf. chrysenteron had optimum activity at $\mathrm{pH}$ 5.0-5.5. Cortinarius obtusus and Russula ochroleuca showed optimum activity at $\mathrm{pH}$ 3.5. According to Wang et al. [31], chitinase from Monascus purpureus (Went) was optimally active at $\mathrm{pH}$ 7. On the other hand, crude chitinase from Penicillium aculeatum NRRL 2129 was active at $\mathrm{pH} 4.0$ but maximum activity of the purified enzyme was at pH 5.5 [3].

The activity of crude and purified enzyme was stabilized by $\mathrm{Mg}^{2+}$ and $\mathrm{Ca}^{2+}$ ions. The activity of the enzyme was inhibited by $\mathrm{Hg}^{2+}$ and $\mathrm{Pb}^{2+}$ ions (Table 2). These results were similar to those observed for chitinase from other microbial sources [31]. The endochitinases from Massilia timonae were stabilized also by $\mathrm{Mn}^{2+}, \mathrm{Ag}^{2+}, \mathrm{Na}^{2+}$, and $\mathrm{Zn}^{2+}$ ions [1].

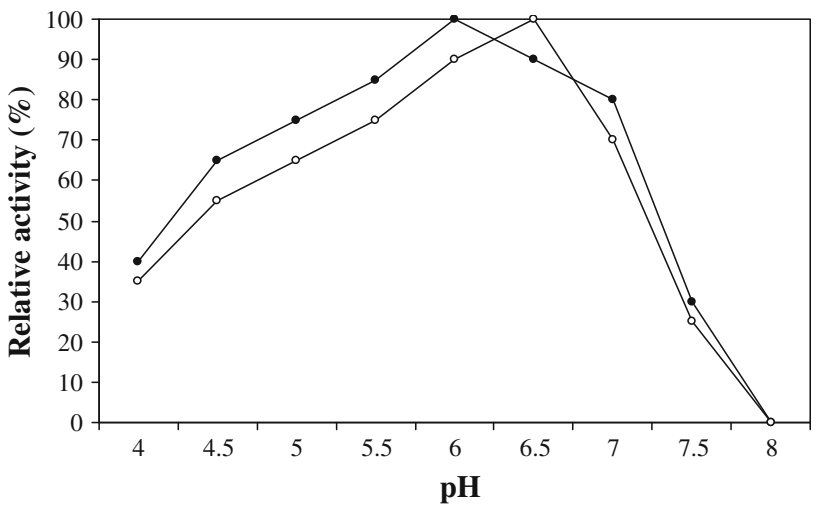

Fig. 6 Effect of $\mathrm{pH}$ on the activity of chitinase from Aspergillus niger LOCK 62 (crude chitinase, filled circle; purified chitinase, and open circle)

Antifungal activity of crude and purified chitinase was observed against Fusarium culmorum, Fusarium solani, and Rhizoctonia solani (Table 3). The growth inhibition of Fusarium culmorum was the strongest both by crude and purified enzymes (70 and $60 \%$, respectively). The growth of Fusarium solani was strongly inhibited by crude chitinase $(73 \%)$. The growth of Botrytis cinerea, Alternaria alternata, and Fusarium oxysporum was not inhibited.

Joo [12] studied the antifungal activity of purified and crude chitinases produced by Streptomyces halstedii. Both purified and crude chitinolytic enzymes inhibited the growth of phytopathogens to some lesser or greater extent. Purified chitinases inhibited the mycelium growth of Alternaria alternata, Colletotrichum gloeosporioides, Fusarium oxysporium, and Stemphylum lycopersici, whereas unpurified chitinases were additionally inhibited by Phytophtora capsci. Despite the fact that many Streptomyces strains produce chitinases, their activities differ considerably. Streptomyces halsteii produces highly active chitinases and this implies that they might be used as a product for biological plant protection. Chitinolytic enzymes may reveal stronger inhibition in relation to mycelia of phytopathogens compared to commercial chitinases. Among the main fungal antagonists, the following are included: Bacillus subtilis, Bacillus cereus, Bacillus licheniformis, Bacillus polymyxa, Bacillus amyliliquefaciens, and Bacillus vallismortis [13, 14, 20, 32]. Among fungi, fungistatic properties of the genus Trichoderma are the most widely researched. The enzymes they produce: chitinases, proteases, and glucanases, which decompose the cell wall of phytopathogens, may find potential use in biocontrol [18]. These enzymes are strong inhibitors of many important plant pathogens. Chitinase produced by Trichoderma is the most widely investigated enzyme of fungicidal effects [8]. $\alpha-(1-3)$-Glucanases 
Table 2 Effect of metal ions on activity of chitinase from Aspergillus niger LOCK 62

\begin{tabular}{lcc}
\hline Metals $(1 \mathrm{mM} / \mathrm{l})$ & \multicolumn{2}{c}{ Relative activity $(\%)$} \\
\cline { 2 - 3 } & Crude chitinase & Purified chitinase \\
\hline None & 100 & 100 \\
$\mathrm{Mn}^{2+}$ & 42 & 32 \\
$\mathrm{Mg}^{2+}$ & 104 & 101 \\
$\mathrm{Zn}^{2+}$ & 72 & 62 \\
$\mathrm{Ca}^{2+}$ & 98 & 105 \\
$\mathrm{Hg}^{2+}$ & 0 & 0 \\
$\mathrm{~Pb}^{2+}$ & 0 & 0 \\
$\mathrm{Cd}^{2+}$ & 44 & 34 \\
\hline
\end{tabular}

Table 3 Antifungal activity of chitinase from Aspergillus niger LOCK 62 against various phytopathogens

\begin{tabular}{lll}
\hline Phytopathogens & \multicolumn{2}{l}{ Antifungal activity $^{\mathrm{a}}$} \\
\cline { 2 - 3 } & Crude chitinase & Purified chitinase \\
\hline Alternaria alternata & - & - \\
Fusarium solani & +++ & + \\
Fusarium oxysporum & - & - \\
Fusarium culmorum & +++ & +++ \\
Botrytis cinerea & - & - \\
Rhizoctonia solani & + & + \\
\hline
\end{tabular}

a Antifungal activity was classified as no inhibition (-; 0-20\%), moderate inhibition $(+; 21-30 \%)$, strong inhibition $(++; 31-50 \%)$, and very strong inhibition $(+++;>50 \%)$

produced by Trichoderma harzianum bind to the cell wall of different pathogenic fungi, including: Aspergillus niger, Botrytis cinerea, Colletotrichum acutatum, and Penicillium aurantogriseum and cause its degradation [2]. Species from the genus Trichoderma have been studied for many years for their usability as bio controlling factors in agriculture [11]. The chitinase from Myrothecium verrucaria degrades the cuticle of the mosquito Aedes aegypti. Chitinase from Beauveria bassiana attacks Galleria mellonella and Trichoplusia ni [6].

The studies described herein confirm the information that compounds of natural origin may significantly contribute to effectively combating plant diseases. It is therefore worthwhile to search in the natural environment for microorganisms capable of combating plant diseases and thus curtail the chemization of the environment.

Open Access This article is distributed under the terms of the Creative Commons Attribution License which permits any use, distribution, and reproduction in any medium, provided the original author(s) and the source are credited.

\section{References}

1. Adrangi S, Faramarzi MA, Shahverdi AR, Sepehrizadeh Z (2010) Purification and characterization of two extracellular endochitinases from Massilia timonae. Carbohydr Res 345:402-407

2. Ait-Lahsen H, Soler A, Rey M, de la Cruz J, Monte E, Llobell A (2001) An antifungal exo- $\alpha-1,3$-glucanase (AGN13.1) from the biocontrol fungus Trichoderma harzianum. Appl Environ Microbiol 67:5833-5839

3. Binod P, Pusztahely T, Nagy V, Sandhya C, Szakàcs G, Pócsi I, Pandey A (2005) Production and purification of extracellular chitinases from Penicillium aculeatum NRRL 2129 under solidstate fermentation. Enzym Microbiol Technol 36:880-887

4. Bradford MM (1976) Rapid and sensitive methods for the quantitation of microgram quantities of protein utilizing the principle of protein-dye binding. Anal Biochem 72:248-254

5. Budi SW, van Tuinen D, Arnould C, Dumas-Gaudut E, Gianinazzi-Pearson V, Gianinazzi S (2000) Hydrolytic enzyme activity of Paenibacillus sp. strain B2 and effect of antagonistic bacterium on cell wall integrity of two soil-borne pathogenic fungi. Appl Soil Ecol 15:191-199

6. Deshpande MV (1999) Mycopesticide production by fermentation: potential and challenges. Crit Rev Microbiol 25:229-243

7. Escott GM, Hearn VM, Adams DJ (1998) Inducible chitinolytic system of Aspergillus fumigatus. Microbiology 144:1575-1581

8. Gohel V, Singh A, Vimal M, Ashwini P, Chatpar HS (2006) Bioprospecting and antifungal potential of chitynolitic microorganisms. Afr J Biotechnol 5:54-72

9. Gooday GW (1997) The many uses of chitinases in nature. Chitin Chitosan Res 3:233-243

10. Hoppe HG (1993) Use of fluorogenic model substrates for extracellular enzyme activity (EEA) measurements of bacteria. In: Sherr BF, Cole JJ, Kemp PF (eds) Handbook of methods in aquatic microbial ecology. Lewis, London, pp 509-512

11. Howell CR (2003) Mechanisms employed by Trichoderma species in the biological control of plant diseases: the history and evolution of current concepts. Plant Dis 87:4-10

12. Joo GJ (2005) Purification and characterization of an extracellular chitinase from the antifungal biocontrol agent Streptomyces halstedii. Biotechnol Lett 27:1483-1486

13. Kavitha S, Senthilkumar S, Gnanamanickam S, Inayathullah M, Jayakumar R (2005) Isolation and partial characterization of antifungal protein from Bacillus polymyxa strain VLB16. Process Biochem 40:3236-3243

14. Kim PI, Chung KC (2004) Production of an antifungal protein for control of Colletotrichum lagenarium by Bacillus amyloliquefaciens MET0908. FEMS Microbiol Lett 234:177-183

15. Laemmli UK (1970) Cleavage of structural proteins during the assembly of the head of bacteriophage T4. Nature 227:680-685

16. Lee YG, Chung KC, Wi SG, Lee JC, Bae HJ (2009) Purification and properties of a chitinase from Penicillium sp. LYG 0704. Protein Expr Purif 65:244-250

17. Lingappa Y, Lockwood JL (1962) Chitin media for selective isolation and culture of actinomyces. Phytopathology 52:317-323

18. Lorito M, Woo SL, Fernandez IG, Colucci G, Harman GE, Pintor-Toro JA, Filippone E, Muccifora S, Lawrence CB, Zoina A, Tuzun S, Scala F (1998) Genes from mycoparasitic fungi as a source for improving plant resistance to fungal pathogens. Proc Natl Acad Sci USA 95:7860-7865

19. Martinez J, Smith DC, Steward GF, Azam F (1996) Variability in ectohygrolytic enzyme activities of pelagic marine bacteria and its significance for substrate processing in the sea. Aquat Microb Ecol 10:223-230 
20. Patel VJ, Tendulkar SR, Chattoo BB (2004) Bioprocess development for the production of an antifungal molecule by Bacillus licheniformis BC98. J Biosci Bioeng 98:231-235

21. Prapagdee B, Kuekulvong Ch, Mongkolsuk S (2008) Antifungal potential of extracellular metabolites produced by Streptomyces hygroscopicus against phytopathogenic fungi. Int J Biol Sci 4: 330-337

22. Pritsch K, Raidl S, Marksteiner E, Blaschke H, Agerer R, Schloterd M, Hartmann A (2004) A rapid and highly sensitive method for measuring enzyme activities in single mycorrhizal tips using 4-methylumbelliferone-labelled fluorogenic substrates in a microplate system. J Microbiol Methods 58:233-241

23. Rattanakit N, Plikomol A, Yano S, Wakayama M, Tachiki T (2002) Utilization of shellfish waste as a substrate for solid-state cultivation of Aspergillus sp. S1-13: evaluation of a culture based on chitinase formation which is necessary for chitin-assimilation. J Biosci Bioeng 93:550-556

24. Rattanakit N, Yano Sh, Plikomol A, Wakayama M, Tachiki T (2007) Purification of Aspergillus sp. S1-13 chitinases and their role in saccharification of chitin in mash of solid-state culture with shellfish waste. J Biosci Bioeng 103(6):535-541

25. Rodriguez J, Copa-Patino JL, Perez-Leblic MI (1995) Purification and properties of a chitinase from Penicillium oxalicum autolysates. Lett Appl Microbiol 20:46-49

26. Sahai AS, Manocha MS (1993) Chitinases of fungi and plants: their involvement in a morphogenesis and host/parasite interaction. FEMS Microbiol Rev 11:317-338
27. Sámi L, Pusztahelyi T, Emri T, Varecza Z, Fekete A, Grallert A, Karanyi Z, Kiss L, Pócsi I (2001) Autolysis and aging of Penicillium chrysogenum cultures under carbon starvation: chitinase production and antifungal effect of allosamidin. J Gen Appl Microbiol 47:201-211

28. Thompson SE, Smith M, Wilkinson MC, Peek K (2001) Identification and characterization of a chitinase antigen from Pseudomonas aeruginosa strain 385. Appl Environ Microbiol 67: 4001-4008

29. van Aalten DMF, Komander D, Synstad B, Gaseidnes S, Peter MG, Eijsink VGH (2001) Structural insights into the catalytic mechanism of a family 18 exo-chitinase. Proc Natl Acad Sci 98: 8979-8984

30. Wang SL, Yieh TC, Shih IL (1999) Production of antifungal compounds by Pseudomonas aeruginosa K-187 using shrimp and crab shell powder as a carbon source. Enzyme Microb Technol 25:142-148

31. Wang SL, Hsiao WJ, Chang WT (2002) Purification and characterization of an antimicrobial chitinase extracellularly produced by Monascus purpureus CCRC31499 in a shrimp and crab shell powder medium. Agric Food Chem 50:2249-2255

32. Zhao Z, Wang Q, Wang K, Brian K, Liu C, Gu Y (2010) Study of the antifungal activity of Bacillus vallismortis ZZ185 in vitro and identification of its antifungal components. Bioresour Technol 101:292-297 